\title{
SISTEM INFORMASI AKUNTANSI POTONGAN PAJAK PPh 21 MENGGUNAKAN VISUAL STUDIO PADA PT. YUSHINDO YASA PERKASA TERNATE
}

\section{TAX ACCOUNTING INFORMATION SYSTEM OF PPh 21 TAX USING VISUAL STUDIO IN PT. YUSHINDO YASA PERKASA TERNATE}

\author{
Ferawati Muhammad ${ }^{1}$, Karmila Djumati ${ }^{2}$, Syahril Hasan ${ }^{3}$, Ditje Lombo ${ }^{4}$ \\ ${ }^{1,2,3}$ Program Studi Komputerisasi Akuntansi \\ Politeknik Sains dan Teknologi Wiratama Maluku Utara \\ ${ }^{4}$ SMA Negeri 1 Kota Ternate \\ ferawatimuhammad38@gmail.com
}

\begin{abstract}
Abstrak
Dalam hal ini peniliti melakukakan penelitian terhadap kegiatan administrasi perusahaan, yang didalamnya terdapat kegiatan yang terkomputerisasi yang akan diusulkan menjadi sebuah aplikasi. Objek penelitian merupakan perusahaan jasa konstruksi bangunan, jalan dan jembatan yang dalam pengelolaan data gaji dan pajak $\mathrm{PPh}$ pasal 21 belum terolah secara maksimal, walaupun telah terolah secara komputerisasi, sehingga perlu adanya suatu aplikasi sistem informasi yang dapat membantu perusahaan mengolah data gaji dan perhitugan pajak penghasilan secara terintegrasi. Salah satu alat yang dapat mendukung hal tersebut adalah dengan pemakaian komputer dan sumber daya manusia yang memadai, sehingga dapat terbentuk sistem informasi yang baik. Tahap kedua yaitu analisis untuk mengetahui kelemahan- kelemahan dari sistem tersebut serta mengevaluasi hasilnya sehingga dapat melakukan perancangan sistem. Aplikasi bantu yang di gunakan adalah visual studio.

Kata kunci: Sistem informasi, Gaji, Pajak penghasilan, Visual Studio

Abstract

In this case, the researcher conducts research on the company's administrative activities, in which there are computerized activities which will be proposed as an application. The object of the study is a company building construction services, roads and bridges that are in the management of salary data and tax PPh Article 21 have not been processed optimally, even though it has been computerized, so there needs to be an information system application that can help companies process payroll and income tax data integrated manner. One tool that can support this is the use of computers and adequate human resources so that a sound information system can be formed. The second stage is analysis to find out the weaknesses of the system and evaluate the results so that they can design the system. The auxiliary application used is a visual studio.
\end{abstract}

Keyword: Information System, Salary, Income Tax, Visual Studio 


\section{PENDAHULUAN}

Perusahaan dituntut untuk lebih efisien, efektif, dan ekonomis dalam menentukan besarnya biaya operasional perusahaan, karena faktor ini adalah salah satu yang terpenting untuk menghadapi persaingan yang semakin ketat dengan perusahaan lain. Dalam melaksanakan kegiatan operasi perusahaan diperlukan adanya manajemen perusahaan yang baik dengan ditunjang oleh personil yang berkualitas agar dapat berkarya secara efisien. Perusahaan betulbetul bersifat selektif dalam menilai potensi manusia tersebut yakni dari segi intelenjensi, integritas dan kompetensi nya, sebagai imbalan bagi potensi manusia tersebut, maka perusahaan memberikan balas jasa berupa Gaji.

Gaji merupakan imbalan kepada pegawai yang deberikan atas tugas-tugas administrasi dan pimpinan yang jumlahnya biasanya tetap secara bulanan.Sebagai warga Negara yang baik maka perlu untuk mematuhi ketentuan perundang-undangan yang berlaku salah satunya adalah adanya kewajiban setiap warga negara yang mempunyai penghasilan sesuai dengan yang telah ditetapkan oleh pemerintah untuk membayar pajak penghasilan.

Salah satu kewajiban seorang pegawai adalah membayar pajak dari penghasilan yang mereka peroleh selama bekerja di perusahaan.Hal tersebut tercantum pada pasal 21."Pajak Penghasilan" atau yang lebih sering kita kenal dengan istilah $\mathrm{PPh}$ 21. Pajak penghasilan (PPh) merupakan pajak yang dipungut kepada subjek pajak atas penghasilan yang diperolehnya subjek pajak yang dipungut dapat berupa subjek perorangan maupun badan usaha.
PT. Yushindo merupakan salah satu perusahaan yang berada di Kota ternate yang bergerak pada bidang jasa konstruksi, saat ini administrasi untuk mengelola perhitungan gaji dan pajak pengasilan pribadi setiap karyawan masih menggunakan Microsoft Excel dimana data-data tersebut dikelola dan dijumlahkan pada setiap sheet, perhitungan-perhitungan potongan PPh 21 pada pajak penghasilan gaji karyawan seiring terjadinya kesalahan karena data yang ada belum tersistem dengan baik, kekurangan lainnya admin harus membuka satu persatu data-data tersebut dan dihitung, disisi lain proses pencarian datapun membutuhkan waktu dikarenakan harus membuka satu persatu data yang ada pada sheet tersebut sehingga dianggap kurang efisien dan membutuhkan suatu sistem yang terintegrasi yang dapat memudahkan admin dalam mengelola datadata potongan pajak $\mathrm{PPh} 21$ secara efisien.

Berdasarkan uraian latar belakang diatas maka peneliti mencoba membuat "Sistem Informasi Akuntansi Potongan Pajak PPh 21 menggunkan Visual Studio pada PT Yushindo Yasa" Perkasa sehingga dapat memudahkan admin dalam mengelola data potongan pajak PPh 21 secara akurat.

\section{Rumusan Masalah}

Bagaimana Merancang Sistem Informasi Akuntansi Potongan Pajak PPh 21 menggunakan Visual Studio pada PT. Yushindo Yasa Perkasa?

\section{LANDASAN TEORI}

\section{Pengertian Sistem Informasi}

Menurut Hartono (2013:16) Sistem informasi adalah seperangkat komponen 
yang saling berhubungan, yang bekerja unutk mengumpulkan dan menyimpan data serta mengolahnya menjadi informasi untuk digunakan.

\section{Karakteristik Sistem Informasi}

Menurut Jogiyanto (2013), Suatu sistem mempunyai karakterisktik atau sifat-sifat tertentu, yaitu mempunyai komponenkomponen (components), batasan sistem (boundary), lingkungan luar sistem (environments), penghubung (interface), masukan (input), keluaran (output), pengolah (process), dan sasaran (objectives).

\section{Pengertian Pajak}

Definisi pajak menurut Resmi dalam bukunya Perpajakan Teori dan Kasus adalah sebagai berikut:"Pajak adalah suatu kewajiban menyerahkan sebagian dari kekayaan ke kas Negara yang disebabkan suatu keadaan, kejadian dan perbuatan yang memberikan kedudukan tertentu, tetapi bukan sebagai hukuman, meurut peraturan yang ditetapkan pemerintah serta dapat dipaksakan, tetapi tidak ada jasa timbale balik dari Negara secara langsung, untuk memelihara kesejahteraan umum." (Resmi, 2009:10).

\section{Pajak Penghasilan Pasal 21}

Definisi PPh pasal 21 menurut Mardiasmo (2013:188) yaitu "Pajak atas penghasilan berupa gaji, upah, honorarium, tunjangan dan pembayaran lain dengan nama dan dalam bentuk apapun sehubungan dengan pekerjaan atau jabatan, jasa, dan kegiatan yang dilakukan oleh orang pribadi”.

\section{Pengertian Gaji}

pengertian gaji menurut Soemarso (2009:307) yaitu “Gaji adalah imbalan kepada pegawai yang diberikan atas tugastgas administrasi dan pimpinan yang jumlahnya biasanya tetap secara bulanan"

\section{Pengertian Visual Basic}

Visual Basic adalah bahasa pemrograman generasi ke tiga dari Microsoft dengan IDE (Integrated Development Environment) atau pemrograman pengembangan terpadu, visual basic dibuat dan dirancang untuk mudah digunakan baik oleh programmer pemula sekalipun (Atmoko, 2013).

\section{Pengertian Crystal Report 8.5}

Irnawan dan Yesni (2011).Crystal Report juga merupakan aplikasi khusus yang digunakan untuk merancang berbagai macam jenis laporan. Pertama kali Crystal Report diciptakan oleh Crystal Services Inc sebagai alat bantu untuk mereka untuk menciptakan Report secara mudah dan cepat. Hal ini dikarenakan kesulitan yang dialami Crystal Services Inc untuk menemukan seorang developer yang khusus menangani pembuatan report untuk software aplikasi akuntansi yang Crystal Services Inc kembangkan.

\section{Microsoft Access}

Menurut Ahmad Iskandar (2003) dalam modulnya yang berjudul Microsoft Access adalah Microsof Access adalah salah satu software database yang berjalan dibawah sistem windows, dengan Microsoft Access kita dapat merancang, memuat dan 
mengelola database dengan cara mudah dan cepat.

\section{Pengertian Flowchart}

Menurut Jogiyanto (Yakub 2012), Bagan alir program (flowchart) merupakan bagan alir yang mirip dengan bagan alir sistem, yaitu untuk menggambarkan prosedur di dalam sistem.

PengertianDiagramAliranData/Data Flow Diagram (DFD)

Ladjamudin (2013:64), “Diagram Aliran Data merupakan model dari sistem untuk menggambarkan pembagian sistem kemodul yang lebih kecil

\section{Pengertian ERD (Entity Relational Diagram )}

Ladjamudin (2013:142), "Entity Relationship Diagram (ERD) adalah suatu model jaringan yang menggunakan susunan data yang disimpan dalam sistem secara abstrak". ERD digunakan oleh professional sistem untuk berkomunikasi dengan pemakai eksekutif tingkat tinggi dalam suatu organisasi.

\section{METODE PENELITIAN}

\section{Metode Pengumpulan Data}

Metode pengumpulan data dalam pemecahan yang harus dilakukan dan diselesaikan dengan cara observasi, wawancara, dan studi pustaka.

1. Observasi

Peneliti terjun langsung ke lapangan untuk mengetahui permasalahan yang terjadi di lapangan.

2. Wawancara
Peneliti Melakukan Tanya jawab dengan Direktur PT. Yushindo Yasa Perkasa bapak Irfan M Saleh Husni,ST

3. Studi Pustaka peneliti mengambil data dari buku maupun sumber informasi lainnya yang dapat mendukung pembuatan sistem informasi ini.

\section{Metode Pengembangan Sistem}

Metode Waterfall Atau Metode air terjun atau yang sering disebut metode waterfall sering dinamakan siklus hidup klasik (classic life cycle), dimana hal ini menggambarkan pendekatan yang sistematis dan juga berurutan pada pengembangan perangkat lunak, dimulai dengan spesifikasi kebutuhan pengguna lalu berlanjut melalui tahapan-tahapan perencanaan (planning), permodelan (modeling), konstruksi (construction), serta penyerahan sistem ke para pelanggan/pengguna (deployment), yang diakhiri dengan dukungan pada perangkat lunak lengkap yang dihasilkan. (Pressman, 2012).

\section{Alat dan Bahan yang digunakan}

Untuk merancang perangkat lunak seperti yang terdapat dalam tujuan, maka bahan yang digunakan dalam penelitian adalah software dan hadware:

Berikut software pendukung yang dipakai untuk merancang sistem informasi Akuntansi Pemotongan Pajak PPh 21 adalah:

1. Sistem Operasi Windows 7 Ultimate

2. Microsoft Office Word 2007 membuat hasil laporan

3. Microsoft Office Acces 2007 untuk membuat database sistem 
4. Visual Basic untuk pemograman

5. Microsoft Visio 2007 untuk membuat Flowchart.

6. Laptop Acer Aspire

7. Mouse Acer

8. Keyboard

9. Printer Canon iP2700

10. Memory 2 GB.

\section{Kerangka Penilitian}

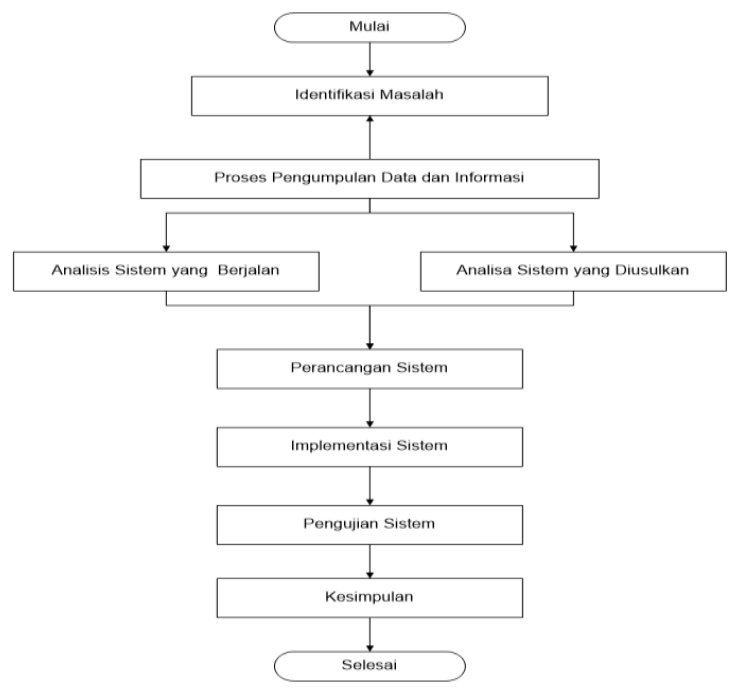

Gambar 1. Kerangka Penilitian

\section{Analisa Sistem yang Berjalan}

Berdasarkan hasil survey dan pengamatan yang dilakukan pada PT. Yushindo Yasa Perkasa, maka didapatkan proses-proses yang terjadi dalam proses penggajian dan Penghitungan Pajak Penghasilan (PPh) 21 PT. Yushindo Yasa Perkasa. Proses-proses tersebut dapat dikelompokkan menjadi dua bagian, yaitu proses perhitungan Gaji, dan proses perhitungan Pajak Penghasilan (PPh) 21.

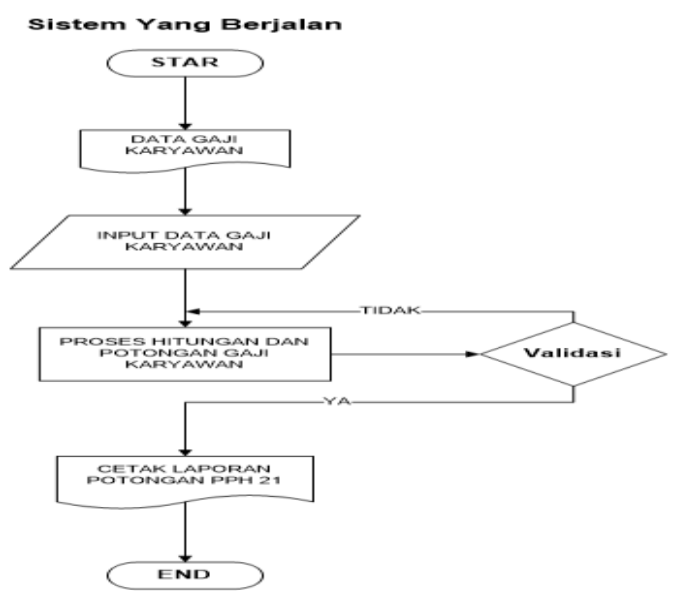

Gambar 2. Sistem yang berjalan

\section{Rancangan System yang Diusulkan}

Sistem yang diusulkan merupakan perbaikan usulan sistem yang sebelumnya dianggap kurang efisien, Berdasarkan masalah yang ada pada sistem yang berjalan maka diusulkan sistem yang baru untuk dapat mempermudah admin atau bendahara dalam mengelola Penghitungan Pajak Penghasilan (PPh) 21, berikut merupakan rancangan usulan sistem yang baru ditampilkan pada gambar flowchart sebagai berikut:

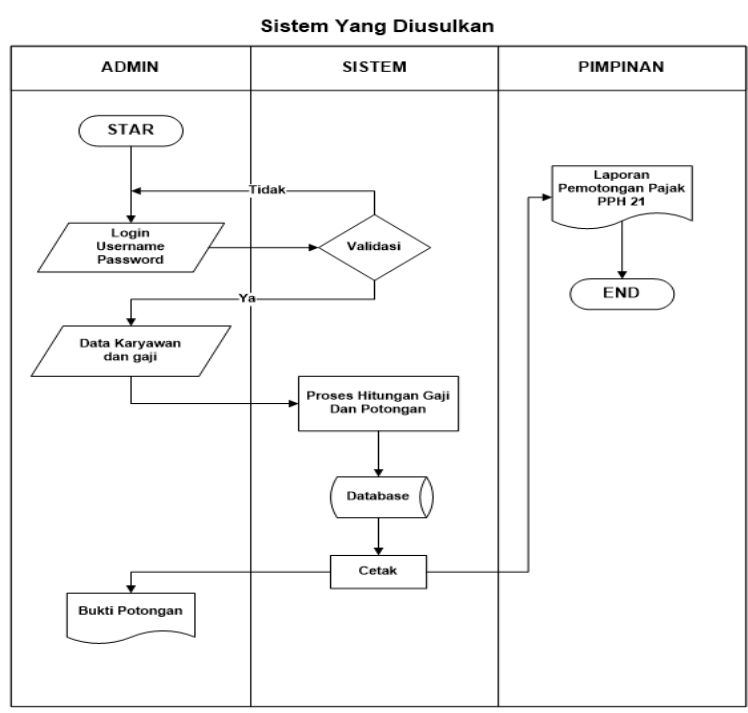

Gambar 3. Flowchart Sistem Yang Diusulkan 


\section{Kebutuhan Fungsional}

Kebutuhan fungsional adalah kebutuhan - kebutuhan yang memiliki keterkaitan langsung dengan sistem. Kebutuhan fungsional dari sistem ini meliputi

1. Kebutuhan Pengguna

a. Mendapatkan informasi data tentang daftar gaji

b. Mendapatkan informasi data tentang tunjangan, lembur dan lain-lain

2. Kebutuhan administrator

a. Melakukan login ke sistem

b. Memanagement data base Sistem.

c. Mengelola data gaji keryawan, tunjangan dan lembur

d. Menampilkan informasi data gaji dan data potongan $\mathrm{PPh} 21$

\section{Kebutuhan Non-Fungsional}

Kebutuhan non-fungsional adalah kebutuhan yang tidak secara langsung terkait dengan fitur tertentu di dalam sistem

1. Sistem berjalan pada processor AMD E2-1800 APU with Radeon.

2. Ram 2.00 GB

3. Berjalan pada Sistem Operasi Windows 7 Ultimate

4. Ms. Acces untuk database

5. Bahasa Pemograman menggunakan Visual Studio

\section{PERANCANGAN SISTEM}

\section{Perancangan Tabel}

\section{Tabel Penguna}

Tabel 1. Tabel Pengguna

\begin{tabular}{|l|l|l|l|}
\hline Field Name & Data Type & Size & Primary Key \\
\hline Kd_Pengguna & Text & 12 & Yes \\
Nm_Lengkap & Text & 40 & No \\
User_Name & Text & 25 & No \\
Pass & Text & 12 & No \\
\hline
\end{tabular}

Tabel Jabatan

Tabel 2. Tabel Jabatan

\begin{tabular}{|l|l|l|l|}
\hline Field Name & $\begin{array}{l}\text { Data } \\
\text { Type }\end{array}$ & Size & $\begin{array}{l}\text { Primary } \\
\text { Key }\end{array}$ \\
\hline $\begin{array}{l}\text { Kode_Jabatan } \\
\text { Jabatan }\end{array}$ & $\begin{array}{l}\text { Text } \\
\text { Text }\end{array}$ & 12 & Yes \\
No
\end{tabular}

\section{Tabel Penggajian}

Tabel 3. Tabel Penggajian

\begin{tabular}{|l|l|l|l|}
\hline Field Name & $\begin{array}{l}\text { Data } \\
\text { Type }\end{array}$ & Size & $\begin{array}{l}\text { Primary } \\
\text { Key }\end{array}$ \\
\hline ID_Penggajian & Text & 12 & Yes \\
Periode & Date/Tim & - & No \\
NIK & e & 25 & No \\
Tunjangan & Text & - & No \\
Lembur & Currency & - & No \\
Uang_Makan & Currency & - & No \\
Transport & Currency & - & No \\
Bonus & Currency & - & No \\
Total_Penerim & Currency & - & No \\
aan & Currency & - & No \\
Pinjaman & Currency & - & No \\
Iuran & Currency & - & No \\
PPh21 & Currency & - & No \\
Total_Potonga & Currency & - & No \\
n & Currency & & \\
Gaji_Bersih & & & \\
\hline
\end{tabular}

\section{Tabel Karyawan}

Tabel 4. Tabel Karyawan

\begin{tabular}{|l|l|l|l|}
\hline Field Name & $\begin{array}{l}\text { Data } \\
\text { Type }\end{array}$ & Size & $\begin{array}{l}\text { Primary } \\
\text { Key }\end{array}$ \\
\hline NIK & Text & 12 & Yes \\
Nama_Karyawan & Text & 40 & No \\
Jenis_Kelamin & Text & 10 & No \\
Jabatan & Text & 15 & No \\
Alamat & Text & 50 & No \\
No_Telp & Text & 12 & No \\
Gaji_Pokok & Currency & - & No \\
\hline
\end{tabular}

\section{Diagram Konteks}

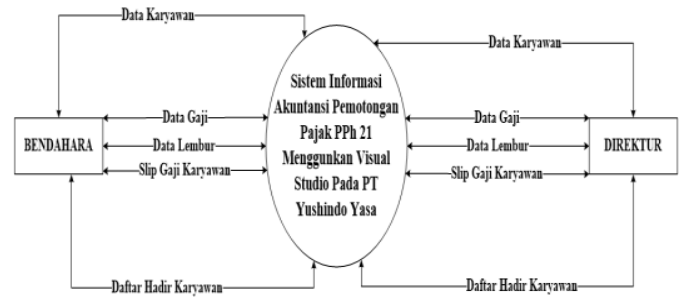


Gambar 4. Diagram Konteks

\section{DFD Level 0}

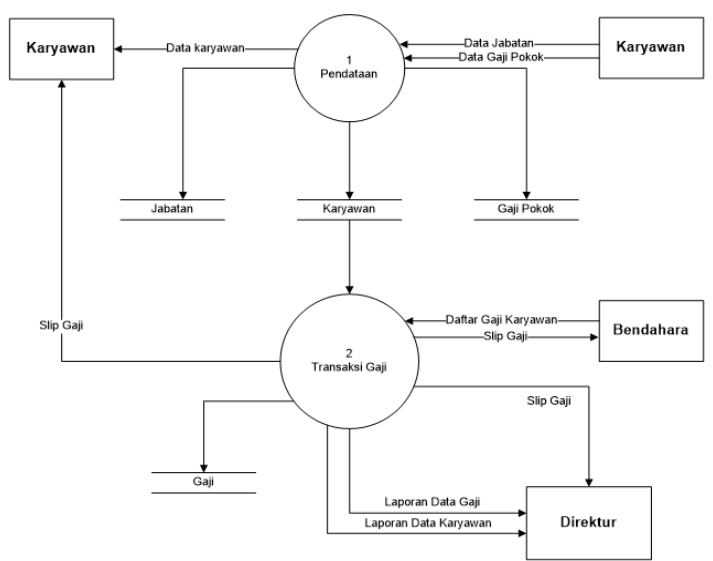

Gambar 5. Diagram Level 0

\section{ERD Relasi Tabel}

Entity Relationship Diagram atau yang biasa disingkat ERD merupakan rancangan model database relasi antar entity dan objek, berikut merupakan hasil rancagan ERD relasi tabel

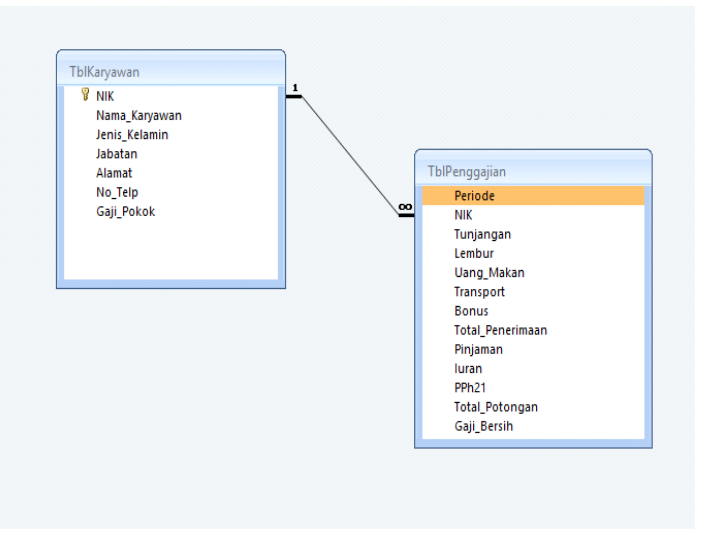

Gambar 6. Relasi Tabel

Entity Relationship Diagram (ERD) Notasi

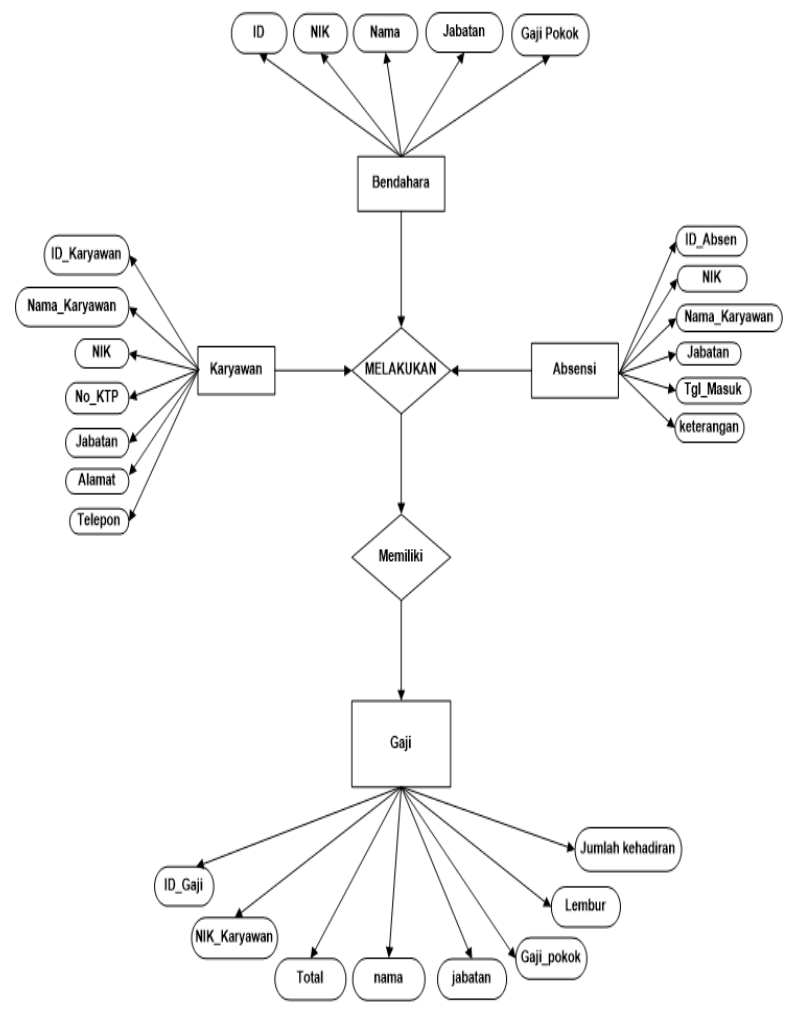

Gambar 7. Erd Notasi

\section{IMPLEMENTASI SISTEM}

Implementasi sistem merupakan tahapan meletakan sistem yang sudah dibuat ke dalam bahasa pemrograman dan nantinya sistem tersebut akan diuji

\section{Menu Utama}

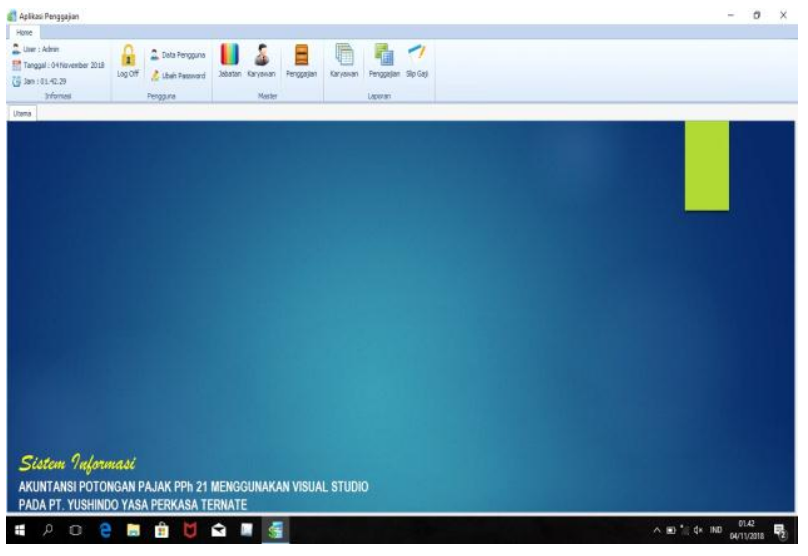

Gambar 8. Tampilan Menu utama 


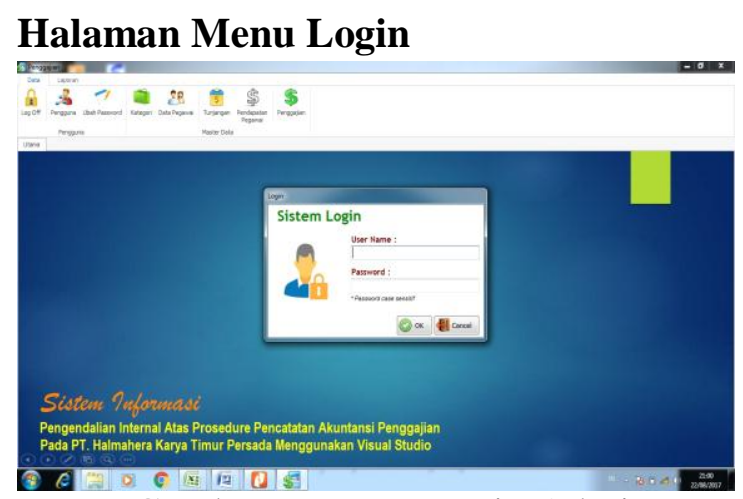

Gambar 9. Menu Login Admin

\section{Halaman Ubah Password}

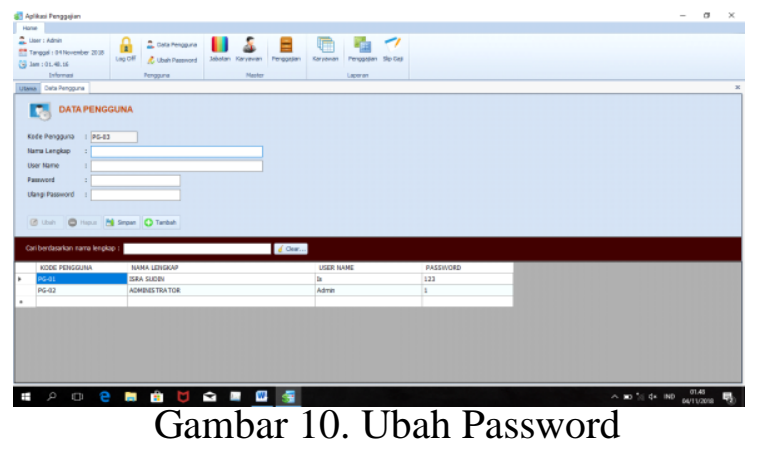

\section{Halaman Menu Data data Pengguna}

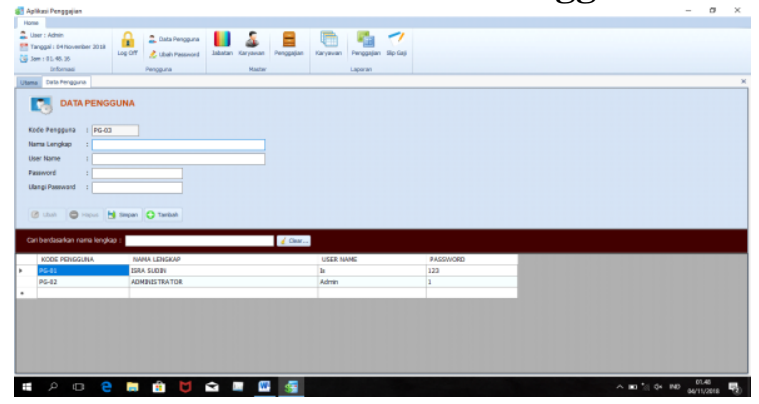

Gambar 11. Menu Data Pengguna

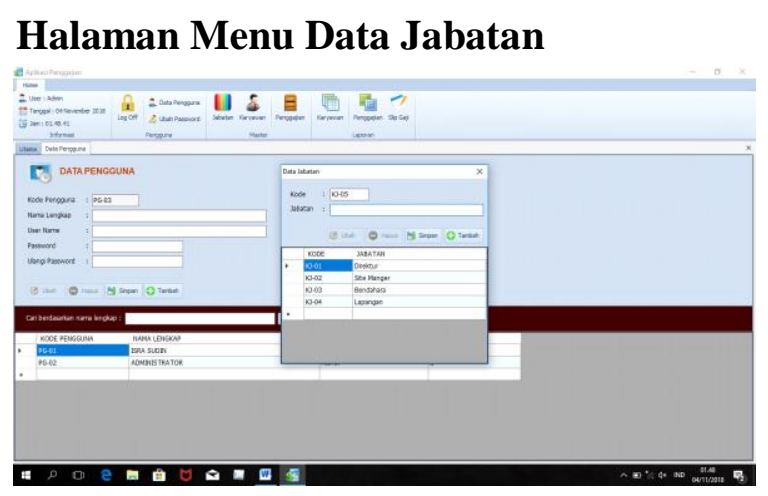

Gambar 12. Menu Data Jabatan

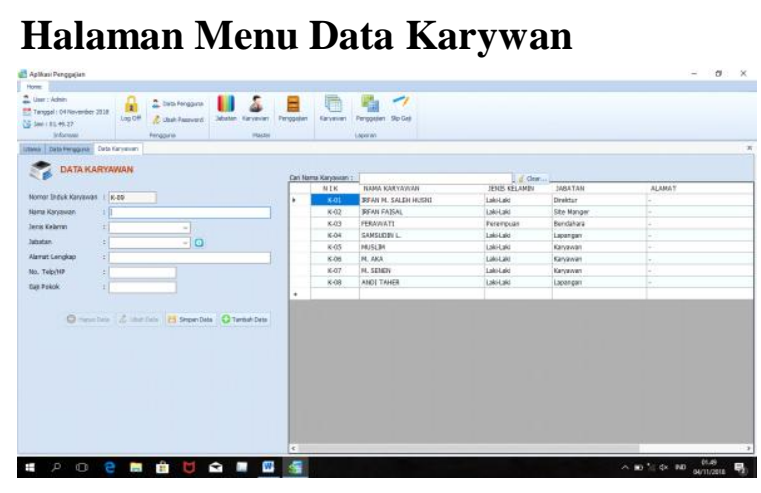

Gambar 13. Menu Data Karyawan

\section{Halaman Menu Penggajian Karywan}

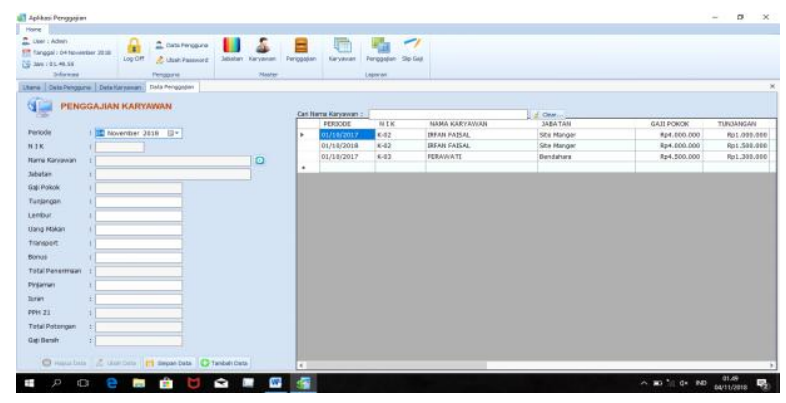

Gambar 14. Menu Penggajian Karyawan

\section{Halaman Menu Laporan Gaji Karyawan}

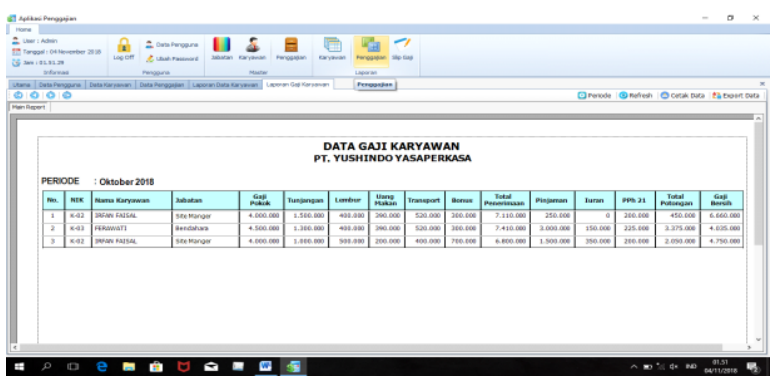

Gambar 14. Menu Laporan Gaji Karyawan Karyawan

\section{Pengujian Sistem Blackbox}

Pengujian Sistem blackbox merupakan metode uji system pada setiap fungsi menumenu pada system yang sudah dibuat, system akan diuji dan dijalankan untuk mengetahui jalan system secara baik atau masih eror, berikut merupakan table uji system

Tabel 5. Uji Blackbox

Volume 4 Nomor 2 | September 2019 


\begin{tabular}{|c|c|c|c|c|}
\hline $\begin{array}{l}\mathrm{N} \\
\mathrm{o}\end{array}$ & $\begin{array}{l}\text { Fungsi } \\
\text { yang } \\
\text { diuji }\end{array}$ & $\begin{array}{l}\text { Cara } \\
\text { Pengujian }\end{array}$ & $\begin{array}{l}\text { Hasil yang } \\
\text { diterapkan }\end{array}$ & $\begin{array}{c}\text { Hasil } \\
\text { Penguji } \\
\text { an }\end{array}$ \\
\hline 1. & Login & $\begin{array}{l}\text { Melakukan } \\
\text { login untuk } \\
\text { membuka } \\
\text { form utama }\end{array}$ & $\begin{array}{l}\text { Menampil } \\
\text { kan form } \\
\text { utama }\end{array}$ & $\begin{array}{l}\text { Ok } \\
\text { Ok }\end{array}$ \\
\hline 2. & $\begin{array}{l}\text { Tamba } \\
\text { h user }\end{array}$ & $\begin{array}{l}\text { Pada form } \\
\text { utama pilih } \\
\text { tambah } \text { user } \\
\text { lalu } \\
\text { masukan } \\
\text { data user } \\
\text { pilih tambah }\end{array}$ & $\begin{array}{l}\text { Menampil } \\
\text { kan form } \\
\text { untuk } \\
\text { menambah } \\
\text { data } \text { user }\end{array}$ & Ok \\
\hline 3. & $\begin{array}{l}\text { Edit } \\
\text { user }\end{array}$ & $\begin{array}{l}\text { Pada form } \\
\text { utama pilih } \\
\text { data } \\
\text { pengguna } \\
\text { klik user } \\
\text { lalu pilih } \\
\text { ubah }\end{array}$ & $\begin{array}{l}\text { Menampil } \\
\text { kan form } \\
\text { untuk } \\
\text { mengubah } \\
\text { data } \text { user }\end{array}$ & Ok \\
\hline 4. & $\begin{array}{l}\text { Hapus } \\
\text { user }\end{array}$ & $\begin{array}{l}\text { Pada form } \\
\text { utama pilih } \\
\text { data } \\
\text { pengguna } \\
\text { klik user } \\
\text { lalu pilih } \\
\text { hapus }\end{array}$ & $\begin{array}{l}\text { Menampil } \\
\text { kan form } \\
\text { untuk } \\
\text { menghapus } \\
\text { data } \text { user }\end{array}$ & Ok \\
\hline 5. & $\begin{array}{l}\text { Ubah } \\
\text { passwo } \\
\text { rd }\end{array}$ & $\begin{array}{l}\text { Pada form } \\
\text { utama pilih } \\
\text { ubah } \\
\text { password, } \\
\text { masukkan } \\
\text { password } \\
\text { lama serta } \\
\text { password } \\
\text { baru lalu } \\
\text { simpan }\end{array}$ & $\begin{array}{l}\text { Menampil } \\
\text { kan form } \\
\text { untuk } \\
\text { mengubah } \\
\text { password }\end{array}$ & Ok \\
\hline 6. & $\begin{array}{l}\text { Tamba } \\
\mathrm{h} \\
\text { jabatan }\end{array}$ & $\begin{array}{l}\text { Pada form } \\
\text { utama pilih } \\
\text { jabatan lalu } \\
\text { klik tambah } \\
\text { data }\end{array}$ & $\begin{array}{l}\text { Menampil } \\
\text { kan form } \\
\text { untuk } \\
\text { menambah } \\
\text { jabatan }\end{array}$ & Ok \\
\hline 7. & $\begin{array}{l}\text { Edit } \\
\text { jabatan }\end{array}$ & $\begin{array}{l}\text { Pada form } \\
\text { utama pilih } \\
\text { jabatan lalu } \\
\text { klik ubah } \\
\text { data }\end{array}$ & $\begin{array}{l}\text { Menampil } \\
\text { kan form } \\
\text { untuk ubah } \\
\text { jabatan }\end{array}$ & Ok \\
\hline 8. & $\begin{array}{l}\text { Hapus } \\
\text { jabatan }\end{array}$ & $\begin{array}{l}\text { Pada form } \\
\text { utama pilih } \\
\text { jabatan lalu } \\
\text { klik hapus } \\
\text { data }\end{array}$ & $\begin{array}{l}\text { Menampil } \\
\text { kan form } \\
\text { untuk } \\
\text { menghapus } \\
\text { jabatan }\end{array}$ & Ok \\
\hline
\end{tabular}

\begin{tabular}{|c|c|c|c|c|}
\hline 9. & $\begin{array}{l}\text { Tamba } \\
\mathrm{h} \\
\text { karyaw } \\
\text { an }\end{array}$ & $\begin{array}{l}\text { Pada form } \\
\text { utama pilih } \\
\text { karyawan,pi } \\
\text { lih tambah } \\
\text { data,masuka } \\
\text { n data } \\
\text { karyawan } \\
\text { lalu simpan } \\
\text { data } \\
\end{array}$ & $\begin{array}{l}\text { Menampil } \\
\text { kan form } \\
\text { untuk } \\
\text { tambah } \\
\text { karyawan }\end{array}$ & Ok \\
\hline 10 & $\begin{array}{l}\text { Edit } \\
\text { karyaw } \\
\text { an }\end{array}$ & $\begin{array}{l}\text { Pada form } \\
\text { utama pilih } \\
\text { karyawan,pi } \\
\text { lih data } \\
\text { karyawan } \\
\text { yang ingin } \\
\text { di edit pilih } \\
\text { ubah data }\end{array}$ & $\begin{array}{l}\text { Menampil } \\
\text { kan form } \\
\text { untuk edit } \\
\text { karyawan }\end{array}$ & Ok \\
\hline 11 & $\begin{array}{l}\text { Hapus } \\
\text { karyaw } \\
\text { an }\end{array}$ & $\begin{array}{l}\text { Pada form } \\
\text { utama pilih } \\
\text { karyawan,pi } \\
\text { lih data } \\
\text { karyawan } \\
\text { yang ingin } \\
\text { di hapus } \\
\text { pilih hapus } \\
\text { data }\end{array}$ & $\begin{array}{l}\text { Menampil } \\
\text { kan form } \\
\text { untuk } \\
\text { hapus } \\
\text { karyawan }\end{array}$ & Ok \\
\hline $\begin{array}{l}12 \\
.\end{array}$ & $\begin{array}{l}\text { Tamba } \\
\mathrm{h} \text { data } \\
\text { gaji }\end{array}$ & $\begin{array}{l}\text { Pada form } \\
\text { utama pilih } \\
\text { penggajian,1 } \\
\text { alu pilih } \\
\text { tambah, } \\
\text { masukkan } \\
\text { data gaji } \\
\text { lalu simpan }\end{array}$ & $\begin{array}{l}\text { Menampil } \\
\text { kan form } \\
\text { untuk } \\
\text { tambah } \\
\text { data gaji }\end{array}$ & Ok \\
\hline $\begin{array}{l}13 \\
.\end{array}$ & $\begin{array}{l}\text { Edit } \\
\text { data } \\
\text { gaji }\end{array}$ & $\begin{array}{l}\text { Pada form } \\
\text { utama pilih } \\
\text { penggajian,1 } \\
\text { alu pilih } \\
\text { ubah data, } \\
\text { masukkan } \\
\text { data gaji } \\
\text { lalu simpan }\end{array}$ & $\begin{array}{l}\text { Menampil } \\
\text { kan form } \\
\text { untuk edit } \\
\text { data gaji }\end{array}$ & Ok \\
\hline $\begin{array}{l}14 \\
.\end{array}$ & $\begin{array}{l}\text { Hapus } \\
\text { data } \\
\text { gaji }\end{array}$ & $\begin{array}{l}\text { Pada form } \\
\text { utama pilih } \\
\text { penggajian,1 } \\
\text { alu pilih } \\
\text { hapus data }\end{array}$ & $\begin{array}{l}\text { Menampil } \\
\text { kan form } \\
\text { untuk } \\
\text { menghapus } \\
\text { data gaji }\end{array}$ & Ok \\
\hline 15 & $\begin{array}{l}\text { Lapora } \\
\text { n data } \\
\text { karyaw } \\
\text { an }\end{array}$ & $\begin{array}{l}\text { Pada form } \\
\text { utama pilih } \\
\text { karyawan, } \\
\text { jika ingin } \\
\text { mencetak } \\
\text { maka pilih } \\
\text { cetak data } \\
\text { dan jika } \\
\text { ingin }\end{array}$ & $\begin{array}{l}\text { Menampil } \\
\text { kan form } \\
\text { untuk } \\
\text { laporan } \\
\text { data } \\
\text { karyawan }\end{array}$ & Ok \\
\hline
\end{tabular}




\begin{tabular}{|c|c|c|c|c|}
\hline & & $\begin{array}{l}\text { mengekspor } \\
\text { data ke } \\
\text { word/pdf } \\
\text { maka pilih } \\
\text { export data }\end{array}$ & & \\
\hline 16 & $\begin{array}{l}\text { Lapora } \\
\text { n gaji } \\
\text { karyaw } \\
\text { an }\end{array}$ & $\begin{array}{l}\text { Pada form } \\
\text { utama pilih } \\
\text { penggajian, } \\
\text { jika ingin } \\
\text { mencetak } \\
\text { maka pilih } \\
\text { cetak data, } \\
\text { jika ingin } \\
\text { mengekspor } \\
\text { data ke } \\
\text { word/pdf } \\
\text { maka pilih } \\
\text { export data, } \\
\text { jika ingin } \\
\text { lihat per } \\
\text { periode } \\
\text { maka pilih } \\
\text { periode dan } \\
\text { jika ingin } \\
\text { me-refresh } \\
\text { maka pilih } \\
\text { refresh }\end{array}$ & $\begin{array}{l}\text { Menampil } \\
\text { kan form } \\
\text { untuk } \\
\text { laporan } \\
\text { gaji } \\
\text { karyawan }\end{array}$ & Ok \\
\hline 17 & $\begin{array}{l}\text { Cetak } \\
\text { slip gaji } \\
\text { karyaw } \\
\text { an }\end{array}$ & $\begin{array}{l}\text { Pada form } \\
\text { utama pilih } \\
\text { slip gaji, } \\
\text { jika ingin } \\
\text { mencetak } \\
\text { maka pilih } \\
\text { cetak data, } \\
\text { jika ingin } \\
\text { mengekspor } \\
\text { data ke } \\
\text { word/pdf } \\
\text { maka pilih } \\
\text { export data, } \\
\text { jika ingin } \\
\text { lihat per } \\
\text { periode } \\
\text { maka pilih } \\
\text { periode dan } \\
\text { jika ingin } \\
\text { me-refresh } \\
\text { maka pilih } \\
\text { refresh }\end{array}$ & $\begin{array}{l}\text { Menampil } \\
\text { kan form } \\
\text { untuk } \\
\text { laporan } \\
\text { gaji } \\
\text { karyawan }\end{array}$ & Ok \\
\hline
\end{tabular}

\section{KESIMPULAN}

Penulis dapat simpulkan bahwa ada beberapa hal sebagai berikut:
1. Memberi kemudahan kepada bendahara dalam memasukan data karyawan, mengolah data gaji karyawan, mencari data karyawan dan mencetak gaji karyawan berdasarkan periode, sehingga dalam pencarian data lebih cepat, Dapat meminimalkan kesalahan dalam memasukan data, proses perhitungan gaji serta meminimalkan kesalahan yang terjadi.

2. Dengan adanya sistem baru ini diharapkan dapat membantu dalam perhitungan gaji karyawan agar lebih cepat, tepat dan mudah.

3. Kelebihan dari sistem ini adalah: Bentuk menu data telah dibuat user, sehingga dalam memasukan data memberikan kemudahan.

\section{DAFTAR PUSTAKA}

Ahmad Iskandar, (2003), Microsoft Access $X P$, Bandung, Penerbit Universitas Komputer Indonesia (UNIKOM).

Atmoko, E. H. 2013. Program Akuntansi beserta Manajemen Aset Menggunakan VB dan SQL Server. Jakarta: PT. Elex Media Komputindo

Bahra Bin Ladjamudin. (2013). Analisis dan Desain Sistem Informasi. Grahallmu. Yogyakarta

Hartono, B. (2013). Sistem Informasi Manajemen Berbasis Komputer. Jakarta. Rineka Cipta.

Irnawan dan Yesni Malau., 2011, Crystal Report, Jakarta : PT Elex Media Komputindo

Jogiyanto HM, (2012), Analisis \& Desain, Ed ke-III. Andi Offset, Yogyakarta Mardiasmo. (2013). Perpajakan Jakarta: Informatika 
Resmi, Siti. (2009). Perpajakan Teori dan Kasus, Surabaya:Airlangga.

Roger, S. Pressman, Ph.D., (2012), Rekayasa Perangkat Lunak (Pendekatan Praktisi) Edisi 7 : Buku 1“, Yogyakarta: Andi.

Soemarso. (2009). Akuntansi Suatu Pengantar. Buku ke 2. Edisi 5. Salemba Empat. Jakarta

Kyky Rizky Zuana, Iwan Sidharta, Sistem Informasi Pemotongan PPH 21 atas Gaji Karyawan PT. Rajawali Tehnik, Jurnal Computech \& Bisnis, Vol 8 No 2 Desember 2014, pp 112-121, ISSN 2442-4943

R Dimas Adityo, Fendy Krisdiyono, Sistem Informasi Pelaporan Pajak Hotel Secara Online Pada Dinas

Pendapatan Kota Pasuruan (Jawa Timur), Prosiding SNATIF Ke -2 Tahun 2015, ISBN: 978-602-1180-211

Lukman Arif Sanjani, Sulis Janu Hartati, Pantjawati Sudarmaningtyas, Rancang Bangun Sistem Informasi Penggajian Pegawai Dan Remunerasi Jasa Medis Pada Rumah Sakit Bedah Surabaya, JSIKA - Jurnal Sistem Informasi \& Komputerisasi Akuntansi, Vol 3, No 1 Tahun 2014, ISSN 2338-137X 